\title{
Growth \& Fate Analysis of Mangalore International Airport - A Case Study
}

\author{
Pavithra Kumari $^{1}$ \& P. S. Aithal ${ }^{2}$ \\ ${ }^{1}$ Research Scholar, College of Management and Commerce, Srinivas University, Mangalore- \\ 575001, India \\ ORCID: https://orcid.org/0000-0003-4541-4242,E-mail: pavithrakumarishetty@gmail.com \\ ${ }^{2}$ Professor, College of Management \& Commerce, Srinivas University, Mangalore - 575001, \\ India \\ ORCID: https://orcid.org/0000-0002-4691-8736; E-mail: psaithal@gmail.com
}

Area of the Paper: Business Management.

Type of the Paper: Research Case Study.

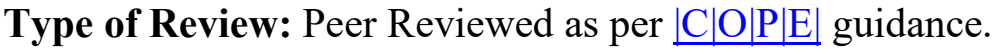

Indexed In: OpenAIRE.

DOI: $\underline{\text { http://doi.org/10.5281/zenodo.4008812. }}$.

Google Scholar Citation: IJCSBE.

\section{How to Cite this Paper:}

Pavithra, K. \& Aithal, P. S. (2020). Growth \& Fate Analysis of Mangalore International Airport - A Case Study. International Journal of Case Studies in Business, IT, and Education (IJCSBE), 4(2), 71-85. DOI: http://doi.org/10.5281/zenodo.4008812.

International Journal of Case Studies in Business, IT and Education (IJCSBE)

A Refereed International Journal of Srinivas University, India.

(C) With Authors.

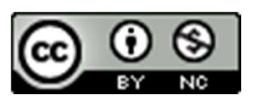

This work is licensed under a Creative Commons Attribution Non-Commercial 4.0 International License subject to proper citation to the publication source of the work.

Disclaimer: The scholarly papers as reviewed and published by the Srinivas Publications (S.P.), India are the views and opinions of their respective authors and are not the views or opinions of the S.P. The S.P. disclaims of any harm or loss caused due to the published content to any party. 


\title{
Growth \& Fate Analysis of Mangalore International Airport - A Case Study
}

\author{
Pavithra Kumari ${ }^{1} \&$ P. S. Aithal ${ }^{2}$ \\ ${ }^{1}$ Research Scholar, College of Management and Commerce, Srinivas University, Mangalore- \\ 575001, India \\ ORCID: https://orcid.org/0000-0003-4541-4242,E-mail: pavithrakumarishetty@gmail.com \\ ${ }^{2}$ Professor, College of Management \& Commerce, Srinivas University, Mangalore - 575001, \\ India \\ ORCID: https://orcid.org/0000-0002-4691-8736; E-mail: psaithal@gmail.com
}

\begin{abstract}
The aviation industry is an expeditiously growing industry in the current scenario. In this regard, Mangalore International Airport is contributing so much to the Aviation industry and engendering revenue to India. The Mangalore Airport commenced functioning in 1951 with the more minute runway at Bajpe. It was called Bajpe Aerodrome, later in the development, it became International Airport and acquired more space by purchasing the land from the local inhabitants. Now its enlarged Mangalore International Airport and accommodating to the international Passengers. In 2012 Mangalore International Airport got a clear status to identify it as International Airport in India. Currently, four airlines are functioning actively. The kingfisher airlines and Jet airways were operating in this airport before their closure. In this paper, we have endeavored to analyze the complete saga of the development of Mangalore International Airport along with its economic analysis. The paper identifies advantages, benefits, constraints, and disadvantages (ABCD listing) of PPP in aviation from various stakeholders' points of view and also highlights the predictive analysis of the aftermath situation where the famous Adani Groups takeover of the Airport business under PublicPrivate Partnership.
\end{abstract}

Keywords: Aviation industry, Airport, MIA, Aerodrome, Saga of development, PPP in Aviation, ABCD Listing.

\section{INTRODUCTION :}

Mangalore is a central city of Dakshina Kannada district which is a major place for trade and commerce which includes industries, seaport, and airport in India. Heading back, Mangalore was a very paramount trading port with the Gulf States, in the 14th century. It experienced varied dynasties and colonial rulers, because of its distinguished location. Mangalore trends as the fastest developing cities in India. As we see, presently, many multinational corporates are establishing in Mangalore, which shows promising economic development within a few years ahead. Astronomically immense infrastructure projects are taken up, and the Banking Industry found its stable location in Mangalore. Mangalore is known as the "cradle of Education" which various streams being introduced in and around the city. This trend attracts may National and Internal passengers which gave a beautiful blend of culture. In Mangalore, we find the best of the food industry, purchase center which shows the purchasing power of the inhabitants. Health care is not at a problem in Mangalore, as we find in numerous health care with multi-specialty hospitals hence medical tourism also is on vogue at present. Various tourist and religious places with an excellent blend of culture is an added attraction to Mangalore. Henceforth, to thrive on the long-distance connectivity to develop commercial activities, Mangalore also focuses on aviation. The economic development of any area should be linked to the infrastructure, so the aviation business portrays a crucial role in terms of the economic development of the country. This will help to contribute to the GDP of the as the transportation of goods and manpower 


\section{International Journal of Case Studies in Business, IT, and Education $\quad$ SRINIVAS (IJCSBE), ISSN: 2581-6942, Vol. 4, No. 2, August 2020.

will increase the revenues and jobs and it will enable the foreign direct investment. The aviation industry will be the enabler of other industries.

Hence the airport in any city will facilitate tourism and trade which will enhance economic growth. So, the airport being a hub to the commercial and economic development, it contributes to the micro and macroeconomics to the system. In this paper, the growth saga and further developments of Mangalore International Airport (MIA) are discussed and analyzed as per research case study guidelines of Company analysis [1-2] and Industry Analysis [3].

\section{RELATED WORK :}

Scholarly case studies analyze the industry or company's organizational and business strategies by identifying certain issues of interest. Such issues are identified based on opportunities and challenges of that industry or organization which can be understood by studying related work of scholarly publications on that industry or organizations various business issues, Table 1 lists some of the important scholarly publications and their issues related to various areas of the airport industry and its business.

Table 1: Scholarly publications related to various issues of Airports

\begin{tabular}{|c|c|c|c|}
\hline $\begin{array}{l}\text { SI. } \\
\text { No. }\end{array}$ & Area & Issues & Reference \\
\hline 1 & Airport & $\begin{array}{l}\text { Facilities and Infrastructure in the new } \\
\text { airport }\end{array}$ & $\begin{array}{l}\text { Bergado, Dennes T., et al. } \\
(2002) .[4]\end{array}$ \\
\hline 2 & Airport & $\begin{array}{l}\text { Airport ground admittance mode } \\
\text { opportunity conduct after the } \\
\text { introduction of new methods. }\end{array}$ & $\begin{array}{l}\text { Jou, R. C., Hensher, D. A., \& Hsu, } \\
\text { T. L. (2011). [5] }\end{array}$ \\
\hline 3 & Airport & $\begin{array}{l}\text { Solar power system as Infrastructure in } \\
\text { the airport }\end{array}$ & $\begin{array}{l}\text { Sukumaran, S., \& Sudhakar, K. } \\
\text { (2017). [6] }\end{array}$ \\
\hline 4 & $\begin{array}{l}\text { Aviation } \\
\text { industry }\end{array}$ & $\begin{array}{l}\text { Employing PPP model to extend } \\
\text { subways. }\end{array}$ & $\begin{array}{l}\text { Soliño, A. S., \& Vassallo, J. M. } \\
\text { (2009). [7] }\end{array}$ \\
\hline 5 & $\begin{array}{l}\text { Airport } \\
\text { Service }\end{array}$ & $\begin{array}{l}\text { Projecting virtual car use for airport } \\
\text { ground access. }\end{array}$ & Cirillo, C., \& Xu, R. (2010). [8] \\
\hline 6 & $\begin{array}{l}\text { Airport } \\
\text { Service }\end{array}$ & $\begin{array}{l}\text { Increasing of Arrival/departure ability to } \\
\text { trade off optimization. }\end{array}$ & Gilbo, E. (2003). [9] \\
\hline 7 & $\begin{array}{l}\text { Aviation } \\
\text { industry }\end{array}$ & $\begin{array}{l}\text { Private Public Partnership model } \\
\text { development as a perspective for the } \\
\text { infrastructure development in an airport. }\end{array}$ & Sambrani, V. N. (2014). [10] \\
\hline 8 & $\begin{array}{l}\text { Airport } \\
\text { Service } \\
\end{array}$ & $\begin{array}{l}\text { Advancements to airport ground handling } \\
\text { and behaviour of multiple airport system. }\end{array}$ & $\begin{array}{l}\text { Monteiro, A. B. F., \& Hansen, M. } \\
\text { (1996). [11] }\end{array}$ \\
\hline 9 & $\begin{array}{l}\text { Aviation } \\
\text { industry }\end{array}$ & $\begin{array}{l}\text { Perception as International airports as } \\
\text { growth poles. }\end{array}$ & Hoare, A. G. (1974). [12] \\
\hline 10 & $\begin{array}{l}\text { Aviation } \\
\text { industry }\end{array}$ & $\begin{array}{l}\text { The economic and environmental costs } \\
\text { analysis of airport operations. }\end{array}$ & Lu, C. (2011). [13] \\
\hline 11 & $\begin{array}{l}\text { Customer } \\
\text { Perception }\end{array}$ & $\begin{array}{l}\text { Adaptation of passengers' perceptions of } \\
\text { airport for improvement of service } \\
\text { quality. }\end{array}$ & $\begin{array}{l}\text { Jin-Woo, P., \& Se-Yeon, J. (2011). } \\
\text { [14] }\end{array}$ \\
\hline 12 & Stress & $\begin{array}{l}\text { Demonstrating the effects of airport noise } \\
\text { on residential housing markets. }\end{array}$ & Levesque, T. J. (1994). [15] \\
\hline 13 & Service & $\begin{array}{l}\text { Level of service analysis for airport } \\
\text { baggage claim of the passenger. }\end{array}$ & $\begin{array}{l}\text { Correia, A. R., \& Wirasinghe, S. } \\
\text { C. }(2010) .[16]\end{array}$ \\
\hline 14 & Service & $\begin{array}{l}\text { Strategy adopted to enhance the airport } \\
\text { service quality. }\end{array}$ & $\begin{array}{l}\text { Chao, C. C., Lin, H. C., \& Chen, } \\
\text { C. Y. (2013). [17] }\end{array}$ \\
\hline 15 & Perception & $\begin{array}{l}\text { passengers have a choice of airline for } \\
\text { their journey. }\end{array}$ & $\begin{array}{l}\text { Chen, H. T., \& Chao, C. C. (2015). } \\
{[18]}\end{array}$ \\
\hline
\end{tabular}




\begin{tabular}{|c|c|c|c|}
\hline 16 & Service & $\begin{array}{l}\text { Performance analysis of modified airport } \\
\text { facilities. }\end{array}$ & George, I. (2013). [19] \\
\hline 17 & Perception & $\begin{array}{l}\text { Customer } \\
\text { Investigating the effects of sales } \\
\text { promotions on customer behavioral } \\
\text { intentions at duty-free shops. }\end{array}$ & $\begin{array}{l}\text { Park, J. W., Choi, Y. J., \& Moon, } \\
\text { W. C. (2013). [20] }\end{array}$ \\
\hline 18 & Perception & $\begin{array}{l}\text { Passengers Expectations of Airport } \\
\text { Service Quality maintained by the } \\
\text { airport. }\end{array}$ & $\begin{array}{l}\text { Yang, J. S., Park, J. W., \& Choi, } \\
\text { Y. J. (2015). [21] }\end{array}$ \\
\hline 19 & Stress & The ground access to the airport. & Akar, G. (2013). [22] \\
\hline 20 & $\begin{array}{l}\text { Aviation } \\
\text { industry }\end{array}$ & $\begin{array}{l}\text { Airport magnetism analysis through } \\
\text { usage of a gravity model. }\end{array}$ & $\begin{array}{l}\text { Wu, C., Han, J., \& Hayashi, Y. } \\
\text { (2011). [23] }\end{array}$ \\
\hline 21 & $\begin{array}{l}\text { Aviation } \\
\text { industry }\end{array}$ & $\begin{array}{l}\text { Airport access and competition among } \\
\text { the airports. }\end{array}$ & $\begin{array}{l}\text { Pels, E., Nijkamp, P., \& Rietveld, } \\
\text { P. (2003). [24] }\end{array}$ \\
\hline 22 & $\begin{array}{l}\text { Aviation } \\
\text { industry }\end{array}$ & $\begin{array}{l}\text { Coping strategies adopted as alternative } \\
\text { approach for planning baggage carousel } \\
\text { capacity expansion. }\end{array}$ & $\begin{array}{l}\text { Yoon, S. W., \& Jeong, S. J. } \\
(2015) .[25]\end{array}$ \\
\hline 23 & $\begin{array}{l}\text { Aviation } \\
\text { industry }\end{array}$ & $\begin{array}{l}\text { Determination of key performance } \\
\text { indicators for measuring airport success. }\end{array}$ & $\begin{array}{l}\text { Eshtaiwi, M., Badi, I., } \\
\text { Abdulshahed, A., \& Erkan, T. E. } \\
\text { (2018). [26] }\end{array}$ \\
\hline 24 & Service & $\begin{array}{l}\text { Maintaining Service quality with robust } \\
\text { design adoption in airport. }\end{array}$ & $\begin{array}{l}\text { Shahin, A., Janatyan, N., \& } \\
\text { Nasirzaheh, N. (2012). [27] }\end{array}$ \\
\hline 25 & $\begin{array}{l}\text { Aviation } \\
\text { industry }\end{array}$ & $\begin{array}{l}\text { Placing of regional airports in modern } \\
\text { competitive markets. }\end{array}$ & $\begin{array}{l}\text { Davison, L., Ryley, T., \& } \\
\text { Snelgrove, M. (2010). [28] }\end{array}$ \\
\hline 26 & $\begin{array}{l}\text { Aviation } \\
\text { industry }\end{array}$ & $\begin{array}{l}\text { Appraisal of airport conditions to attract } \\
\text { foreign low-cost air carriers. }\end{array}$ & $\begin{array}{l}\text { Lu, H. A., \& Mao, Y. R. (2015). } \\
{[29]}\end{array}$ \\
\hline 27 & $\begin{array}{l}\text { Aviation } \\
\text { industry }\end{array}$ & $\begin{array}{l}\text { Transforming Organizational Capabilities } \\
\text { into Agile IT Adoption. }\end{array}$ & $\begin{array}{l}\text { Goh, J. C. L., Zuo, M., \& Pan, S. } \\
\text { L. (2010). [30] }\end{array}$ \\
\hline 28 & Perception & $\begin{array}{l}\text { Passengers' Perception Toward Airport } \\
\text { Service Quality (ASQ). }\end{array}$ & $\begin{array}{l}\text { Kurniawan, R., Sebhatu, S. P., \& } \\
\text { Davoudi, S. (2017). [31] }\end{array}$ \\
\hline 29 & $\begin{array}{l}\text { Aviation } \\
\text { industry }\end{array}$ & $\begin{array}{l}\text { International airport location selection } \\
\text { and planning of airport design and } \\
\text { infrastructure. }\end{array}$ & $\begin{array}{l}\text { Yao, S. M., Chen, C. H., Wang, S. } \\
\text { G., CUI, X., \& CHEN, Z. G. } \\
\text { (2006). [32] }\end{array}$ \\
\hline 30 & $\begin{array}{l}\text { Aviation } \\
\text { industry }\end{array}$ & $\begin{array}{l}\text { Adoption of PPP model for the } \\
\text { Greenfield airport development. }\end{array}$ & $\begin{array}{l}\text { Rajan, T. A., Sharad, S., \& Sinha, } \\
\text { S. (2009). [33] }\end{array}$ \\
\hline 31 & $\begin{array}{l}\text { Aviation } \\
\text { industry }\end{array}$ & $\begin{array}{l}\text { A gap analysis model for improving } \\
\text { airport service quality. }\end{array}$ & $\begin{array}{l}\text { Tsai, W. H., Hsu, W., \& Chou, W. } \\
\text { C. (2011). [34] }\end{array}$ \\
\hline 32 & Perception & $\begin{array}{l}\text { Passenger Perception on facilities } \\
\text { provided in the Airport Terminal and its } \\
\text { Performance. }\end{array}$ & Adisasmita, S. A. (2012). [35] \\
\hline 33 & $\begin{array}{l}\text { Aviation } \\
\text { industry }\end{array}$ & $\begin{array}{l}\text { Strategy adopted to meet the New } \\
\text { international airport services and the } \\
\text { competitiveness of International Airport. }\end{array}$ & $\begin{array}{l}\text { Lieshout, R., \& Matsumoto, H. } \\
\text { (2012). [36] }\end{array}$ \\
\hline 34 & $\begin{array}{l}\text { Aviation } \\
\text { industry }\end{array}$ & $\begin{array}{l}\text { Evaluation of sustainable growth and } \\
\text { development in aviation industry. }\end{array}$ & $\begin{array}{l}\text { Walala, M., \& Mutinda, E. M. } \\
\text { (2013). [37] }\end{array}$ \\
\hline 35 & Customer & $\begin{array}{l}\text { A strategic framework for assessing level } \\
\text { of service of the airport terminals. }\end{array}$ & $\begin{array}{l}\text { Müller, C., \& Gosling, G. D. } \\
\text { (1991). [38] }\end{array}$ \\
\hline 36 & $\begin{array}{l}\text { Aviation } \\
\text { industry }\end{array}$ & $\begin{array}{l}\text { Strategy for development of Sustainable } \\
\text { airport energy management. }\end{array}$ & $\begin{array}{l}\text { Baxter, G., Srisaeng, P., \& Wild, } \\
\text { G. (2018). [39] }\end{array}$ \\
\hline 37 & $\begin{array}{l}\text { Aviation } \\
\text { industry }\end{array}$ & $\begin{array}{l}\text { Renovation of an old terminal by } \\
\text { transforming it into a Nearly Zero Energy } \\
\text { Building (NZEB) for the sustainable } \\
\text { growth of airport. }\end{array}$ & $\begin{array}{l}\text { Falvo, M. C., Santi, F., Acri, R., \& } \\
\text { Manzan, E. (2015, June). [40] }\end{array}$ \\
\hline
\end{tabular}




\section{International Journal of Case Studies in Business, IT, and Education SRINIVAS (IJCSBE), ISSN: 2581-6942, Vol. 4, No. 2, August 2020.

\begin{tabular}{|c|c|c|c|}
\hline 38 & $\begin{array}{l}\text { Aviation } \\
\text { industry }\end{array}$ & $\begin{array}{l}\text { Strategy for development of Greenfield } \\
\text { Airports in India. }\end{array}$ & Gupta, A. (2013). [41] \\
\hline 39 & $\begin{array}{l}\text { Aviation } \\
\text { industry }\end{array}$ & $\begin{array}{l}\text { Motivation for the environmental } \\
\text { development with go green concept as } \\
\text { commitment of aviation industry to } \\
\text { protect the environment. }\end{array}$ & $\begin{array}{l}\text { Lynes, J. K., \& Dredge, D. (2006). } \\
\text { [42] }\end{array}$ \\
\hline 40 & $\begin{array}{l}\text { Aviation } \\
\text { industry }\end{array}$ & $\begin{array}{l}\text { Strategy adopted to Manage Solid Waste } \\
\text { produced in airport. }\end{array}$ & Parameshwar, H. K. (2011). [43] \\
\hline 41 & $\begin{array}{l}\text { Customer } \\
\text { satisfaction }\end{array}$ & $\begin{array}{l}\text { The effect of airport choice traits on } \\
\text { airport users' satisfaction and behavioral } \\
\text { intentions. }\end{array}$ & $\begin{array}{l}\text { Kim, M. H., Park, J. W., \& Choi, } \\
\text { Y. J. (2016). [44] }\end{array}$ \\
\hline 42 & $\begin{array}{l}\text { Aviation } \\
\text { industry }\end{array}$ & $\begin{array}{l}\text { Economic, Environmental, and Social } \\
\text { impact analysis of airport infrastructure } \\
\text { from the perspective of sustainability }\end{array}$ & Li, L., \& Loo, B. P. (2016). [45] \\
\hline 43 & Customer & $\begin{array}{l}\text { Investigating satisfaction level with the } \\
\text { effect of experience in an Airport based } \\
\text { on Pleasure, Satisfaction, and Airport } \\
\text { Image. }\end{array}$ & $\begin{array}{l}\text { Ryu, Y. K., \& Park, J. W. (2019). } \\
\text { [46] }\end{array}$ \\
\hline 44 & $\begin{array}{l}\text { Aviation } \\
\text { industry }\end{array}$ & $\begin{array}{l}\text { The opportunities and challenges faced in } \\
\text { civil aviation at India. }\end{array}$ & Bhadra, D. (2008). [47] \\
\hline 45 & $\begin{array}{l}\text { Aviation } \\
\text { industry }\end{array}$ & $\begin{array}{l}\text { Investment opportunities in the next } \\
\text { phase of development through } \\
\text { privatization of airports in India. }\end{array}$ & Raghunath, S. (2010). [48] \\
\hline 46 & Aviation & $\begin{array}{l}\text { The opportunities and challenges of civil } \\
\text { aviation in India pertaining to } \\
\text { Communication, Navigation, and } \\
\text { Surveillance in Air Traffic Control } \\
\text { Management. }\end{array}$ & Bhadra, D. (2009). [49] \\
\hline 47 & Employees & $\begin{array}{l}\text { Efficiency Analysis of Airports in India } \\
\text { in a Changing Environment in the world. }\end{array}$ & $\begin{array}{l}\text { Kashiramka, S., Banerjee, R., } \\
\text { Kumar, A., \& Jain, P. K. (2016). } \\
{[50]}\end{array}$ \\
\hline 48 & $\begin{array}{l}\text { Aviation } \\
\text { industry }\end{array}$ & $\begin{array}{l}\text { Importance, and challenges faced by } \\
\text { airports privatization of airports in India. }\end{array}$ & Manzoor, K. P. (2010). [51] \\
\hline
\end{tabular}

\section{OBJECTIVES OF THE CURRENT STUDY :}

Based on published related works on the airport industry, the following objectives are identified for the present analysis of Mangalore International Airport.

(1) The Growth Saga of Mangalore International Airport (MIA).

(2) Analysis of the Airport strategies in coping with the competition.

(3) Economic analysis of Mangalore International Airport.

(4) Analysis of the problems faced by the Mangalore International airport including Strategic positions of MIA for its Business Expansion.

(5) Challenges and Opportunities of MIA under the new PPP Model.

(6) ABCD Analysis of PPP Model of MIA from various stakeholders' points of view.

(7) Predictive analysis ofthe performance of MIA under the New Management Group.

\section{THE GROWTH SAGA OF MANGALORE INTERNATIONAL AIRPORT :}

The Mangalore International Airport is situated near Bajpe, on the northeast side of Mangalore city, nearly 13 kilometers from the heart of the city. It is about $300 \mathrm{~m}$ in elevation, and $4-5 \mathrm{~km}$ away from the seacoast. It is known for the tabletop runway, which is on the top of a hill. The present Mangalore International Airport was then called as Bajpe Aerodrome, which was started in 1951, December 25th. It is the second major engaged airport, the first in rank being the Kempegowda International Airport in Bangalore. The airport had a small runway, of $1600 \mathrm{~m}$ which could serve the particular model of aircraft 
which is called as Boeing 737-400 size aircraft. In the year 2006, the runway was developed which could permit the landing of slightly larger aircraft like the Airbus A319 of Kingfisher Airline. MIA is the first airport in Karnataka State which is having two runways and the runway constructed in concrete. The second runway, constructed in 2006, is $8,038 \mathrm{ft}$ long. The first flight carried 95 passengers from Bangalore through Jet Airways. So, in 2012, Mangalore International Airport could witness the safe landing of Airbus A310 in the airport by carrying the passengers from Hajj pilgrims of Saudi Arabia. The airport was initially serving the domestic travel, which was developed in 2006, to make its fly Air India Express to Dubai. This was the greatest milestone achieved. A step ahead, for six years then, the Mangalore airport was serving as the customs airport, in 2012, it was awarded the status of International Airport. Then onwards Mangalore witnessed the growth of the aviation economy, which accelerated the economy. It is having the biggest terminals with capabilities of handling 34 million passengers per year. Mangalore airport presently has two terminals, $1 \& 2$. Terminal 1 is the domestic terminal where flights carry passengers to major destinations including Mumbai, Chennai, Delhi, Hyderabad, Bangalore, and Surat.

\section{ANALYSIS OF THE AIRPORT STRATEGIES IN COPING WITH THE COMPETITION :}

Mangalore International Airport is a moderate-sized airport in India and situated in the south zone of Karnataka, India. It has several flights with nonstop travel for 13 destinations in 6 countries. As per the information, Mangalore had the first International flight in 2006 when the Air India Express flew to Dubai. It was made known as customs airport, for six more years, and in 2012, Bajpe Airport was privileged as the International Airport. May 15 was incredibly special as the Mangalore airport inaugurated Rs 180-crore integrated terminal building at the airport. This attracted many travellers with more specialized services to the customers [5]. 2010 also witnessed the service of flying 8.22 lakh passengers and in 2011, it could be analyzed that the major contribution for the Mangalore airport passenger traffic was by the International passenger which saw the rise in $4.10 \%$ at that duration. Most of the passenger was flying towards west Asia. During that duration, the airport handled 6.01 lakh domestic passengers in 2011, which showed a rise from 5.95 passengers in 2010 . This statistic although showed a considerable increase, is not that it survived without a problem. There was frequent cancellation of flight by the kingfisher to a few destinations and increase the flight cost during the seasons of frequent travel. However, the productivity did not affect, as new destinations like Hyderabad and Chennai were connected by Spice jet. Also, the traveler's contributed by taking connecting flights to various other places, which increased the revenue.

With the advent of developing the runway in 2012, the revenue of the airport and other added services like additional café, waiting for a lounge, parking slots, etc, the increased from Rs. 8.3 million in 2006 -07 to Rs. 42.64 crores in 2011-12. In the year 2012-13, the airport could be able to serve around 1.02 million passengers with 11,940 aircraft activities. This brought in the revenue of Rs. 506.6 million, with a functional economic benefit of Rs. 164.9 million. In the year 2013-14, 1.25 million passengers were served and the airport having revenue of Rs. 638.9 million.

With a technical feasibility study of the airport, the expansion of the runway by one kilometre was planned. Financial feasibility study reported that to expand as there was a project which planned for the land acquisition of 289.33 acres of land which needed Rs. 3,399.36 lakh. Hence the whole project is estimated for Rs. 1,120 crores. Expansion of the runway was not an easy task, as it involved filling the valleys of three adjacent hills.

This was a historical milestone of Mangalore International Airport because the expansion will be able to serve for the bigger aircraft which will increase the traveler's load. The longest journey voyage from Mangalore IXE is a 2,058-mile non-stop which is routed to Kuwait City (KWI). This is served by AirIndia Express, which travels for 4 hours 35 minutes to reach destiny. Mangalore International airport flies 4 airlines like Air India Express (IX) for 7 destinations, Indigo Airlines (6E) with 5 destinations, Spice Jet (SG) with 3 destinations, and Air India (AI) with 2 destinations. 


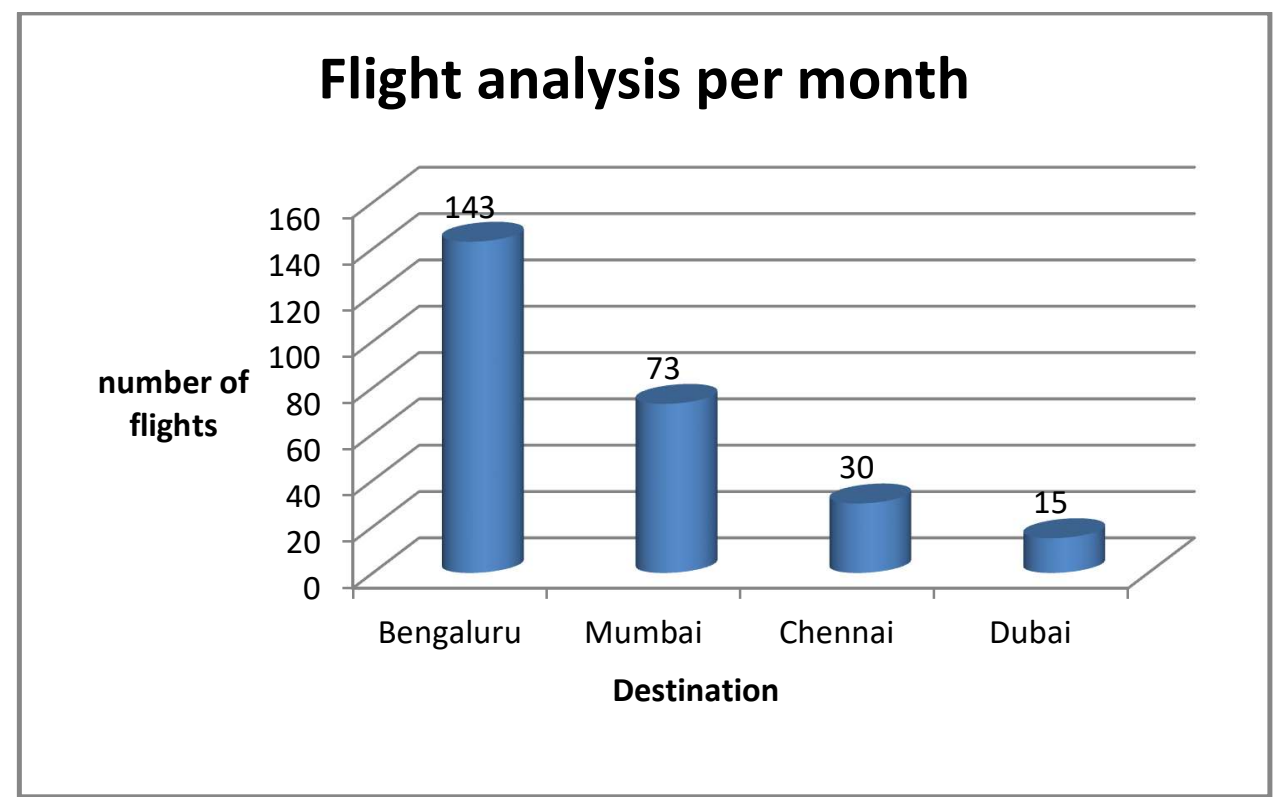

Fig. 1: Airport analysis of the carriers (per month) [2]

The chart in figure 1 shows the number of flights serves at Mangalore International airport to major destinations per month averaged during last few years.

\section{ECONOMIC ANALYSIS OF MANGALORE INTERNATIONAL AIRPORT :}

Before the developmental process was active after 2006, the airport had various problems, especially in the economic area. The airport incurred a loss of Rs. 2.5 crore annually from 1998 to 2006 . This was because of the low frequency of the aircrafts movement which was only 12 per day. To improve this later the airport planned various strategies to strengthen its financial position. With this, the airport had its operating profits increasing to Rs. 9.5 crore by 2011-12, as against, 83 lakhs in 2006-07. This development was found due to the increase in domestic and international aircraft movement. As per the report [4] by Mr. M. R. Vasudeva the airport revenue was 42 crores for the year 2011-12, whereas the expenditure was Rs. 32.5 crore. The main reason for this profit was the aircraft movement increased to 32 schedules per day to main cities in India and various other places in the Gulf.

Also, it was seen after the expansion of the second runway in 2006, International flights were permitted to land, also the larger Boeing aircraft. With the increase in traffic movement, the revenue also increased, as the airport could charge for landing fees, route navigational facility charges, parking bay fee and passenger service charges. There was also non-traffic revenue, which was collected, including rent from concessionaires, royalty from tendered contracts and license fees. However, the airport had the expenses on the airport staff salaries, CISF deputation salaries, building maintenance and other recurring expenses [4].

\section{ANALYSIS OF THE PROBLEMS FACED BY THE MANGALORE INTERNATIONAL AIRPORT :}

As the process of development of the airport enhanced and income started increasing, the airport also faced major problems. Within a week of the new terminal building inauguration in May, the airport was shocked by the crash of the Dubai- Mangalore flight IX 812 on May 22. 158 death was recorded whereas eight of the passengers survived. The contributory factors [7] of the accidents were the captain of the flight was in sleep disorder and was unable to make the rational and fair judgment, so, he has taken compromising judgment during the landing and which caused to the accident severely. Another possible reason for the problem was there was a lack of a Radar Control system and the descent approach of the aircraft was into the shorter distance on DME as compared to the normal approach. The next possibility ground for the accident was ignorance and uncertainty of the instructions encouraging the 'co-pilot' to initiate a 'go around', which might have resulted in the crash as per the 
report. Finally, the study ends up stating that the main reason for the accident and safety failure is captain failure to suspend the un-steadied approach and tenacity in continuing with the landing in spite of having to continue three calls and multiple warnings from the EGPWS and first officer to go ground. There were several contributing factors also caused to the accident like sleep disorder of captain, the non-Radar system in an airport, descent approach in the shorter distance on DME, non-plan by the Flight crew, and also uncertainty in the instructions given by the co-pilot, etc.

After the report by the court, suggestions on the safe flight were elicited, and it was analyzed that the priority should be given for the human resource management, training of the staff, time schedule, to reduce fatigue, etc. DGCA identified that there are eleven airports are not safe in India in terms of landing the aircraft. So DGCA reframed its safety manual for the improvement of safety in these airports by widening and lengthening the runways with proper runway marking and by installing VASI and PAPI lights, as well as implementing the rules for the regular maintenance and inspection of the runways. As per the changes brought in 2017, in Mangalore International Airport aircraft movements in the apron must be stopped during the landing of other aircraft and till it reaches safely to the apron. As the PPP model is increasing in the modern aviation industry for a different service-oriented reason. So even India thought to bring efficiency in airports and decided to go for the privatization of major airports. As a result, the Mangalore International airport has been won by Adani Group is bidding along with other five major airports. AAI opted for a new method of revenue-generating by privatizing these major airports. It is in the process of being taken over by the Adani group operation.

In this section, we have analyzed the complete history of Mangalore International Airport along with the growth of airline operations as well as reported accidents. After analyzing the Mangalore International Airport, by studying the growth prospects of Mangalore airport and its ability to provide services to several international destinations to become one of the best airports in the list Airports in India.

\subsection{Strategic positions of MIA for its Business Expansion:}

Various strategies were found to expand the business by the MIA. After the handover of the MIA by the Union government on lease to the Adani group, with the lease for maintenance of the airport for 50 years, the Business expansion is planned effectively. The strategy for the promotion of business is done by the effective operation of the airport, development work of the terminal, maintenance will be undertaken throughout the period of the lease. Priority will be given for the expansion of the runway. The company will also undertake the airport assets, staff functioning, source of income, security system, and operation of the airlines. Employment enhancement in the airport for the localities will be prioritized.

The city will be developed with malls and complexes. The business expansion will be done, through increasing the passenger charges, monthly rent of the commercial stalls, parking fees. The charges for the aircraft landing and parked in hangars also will be hiked which a factor of an increase in the revenue of the airport.

\section{AFTERMATH - FATE ANALYSIS OF MIA WITH NEW MANAGEMENT UNDER PPP :}

Mangalore International airport is taken over by the Adani group based on PPP for the next 50 years on lease. The company took over the airport for the operation, management, and development to bring efficiency in delivery, expertise, enterprise, and professionalism and also to harness the needed investment in the public sector.

\subsection{PPP Model \& Takeover of MIA by Adani Group:}

Mangalore International airport service increased for around 30\% from 2017 to 2018 could witness for the growth in the aviation industry. In 2018, the Union Cabinet, when decided to develop the airports under the PPP model, included Mangalore International airport, which was the step for another milestone. Because of this, we could witness the world-class infrastructure at the airport, efficient delivery, and service to the customers, which increased the revenue to the airport. Indirectly this development increased the job opportunity to the people in the surrounding area of the airport. Another important development was seen as it focused on developing the air navigation infrastructure in the whole country.

Adani enterprises were the highest bidder for Mangalore International Airport, when PPP mode was offered, which also bidding for Ahmedabad, Lucknow and was approved. This included the concession 
agreement signed with Adani Enterprise with AAI. Adani group is an Indian Multinational conglomerate, headquarters in Ahmedabad. It is India's largest port developer and operator which has an annual revenue of over US\$ of 13 billion. (ref: empowering India, shaping a new future).

8.2 ABCD Analysis of PPP Model of MIA from Organizational Point of View:

$\mathrm{ABCD}$ analysis is a framework for qualitative and quantitative analysis of systems, concepts, technology, ideas, and strategies developed in the year 2015 [58-59]. This framework suggests identifying advantages (A), benefits (B), constraints (C), and disadvantages (D) of the system. Here, we have identified the advantages, benefits, constraints, and disadvantages of MIA from organizational and customers' points of view as determinant issues under the qualitative framework of ABCD analysis technique. Table 2 depicts the ABCD analysis of MIA from an Organizational point of view.

Table 2: ABCD analysis from Organizational point of view

\begin{tabular}{|c|c|c|c|c|c|}
\hline $\begin{array}{l}\text { S. } \\
\text { N } \\
\text { o. }\end{array}$ & $\begin{array}{l}\text { Determin } \\
\text { ant } \\
\text { Issues } \\
\end{array}$ & Advantages & Benefits & Constraints & Disadvantages \\
\hline 1 & $\begin{array}{l}\text { Public } \\
\text { Partner } \\
\text { (Govt.) }\end{array}$ & $\begin{array}{l}\text { 1. Expansion of } \\
\text { airport } \\
\text { 2. Increased passenger } \\
\text { 3. Increased } \\
\text { infrastructure } \\
\text { 4. Increased } \\
\text { navigation }\end{array}$ & $\begin{array}{l}\text { 1. Services } \\
\text { extended to abroad } \\
2 . \text { Increased } \\
\text { revenue } \\
\text { 3. Timely quality } \\
\text { service to } \\
\text { passenger } \\
\text { 4. Increased } \\
\text { employment }\end{array}$ & $\begin{array}{l}\text { 1. Political } \\
\text { interference } \\
\text { 2. Kannur } \\
\text { airport }\end{array}$ & $\begin{array}{l}\text { 1. Increase in } \\
\text { bribery } \\
2 . \text { Flights } \\
\text { diverting to } \\
\text { Kannur }\end{array}$ \\
\hline 2 & $\begin{array}{l}\text { Private } \\
\text { Partner } \\
\text { (Adani } \\
\text { Group) }\end{array}$ & $\begin{array}{l}\text { 1. Expansion of the } \\
\text { terminal building } \\
\text { 2. Revenue generation } \\
\text { from the airline } \\
\text { office, trolleys, rent, } \\
\text { shops, hoarding of } \\
\text { advertisement etc. } \\
\text { 3. Increase in } \\
\text { employment } \\
\text { 4. Enhancement of the } \\
\text { professional standard } \\
\text { of the services }\end{array}$ & $\begin{array}{l}\text { 1. Increased } \\
\text { customer } \\
\text { satisfaction } \\
\text { 2. Increased } \\
\text { revenue } \\
\text { 3. Increased } \\
\text { passengers/flyers } \\
\text { 4. Development of } \\
\text { economy }\end{array}$ & $\begin{array}{l}\text { 1. Pandemic } \\
\text { effect } \\
\text { 2. More } \\
\text { policies }\end{array}$ & $\begin{array}{l}\text { 1. Loss in } \\
\text { revenue } \\
\text { 2.Need to } \\
\text { invest more to } \\
\text { maintain } \\
\text { international } \\
\text { standards }\end{array}$ \\
\hline 3 & $\begin{array}{l}\text { Employees } \\
\text { of Airport }\end{array}$ & $\begin{array}{l}\text { 1. Better work } \\
\text { experience } \\
\text { 2. Increase } \\
\text { professionalism } \\
\text { 3. Better income } \\
\text { through salary } \\
\text { 4.More training and } \\
\text { development }\end{array}$ & $\begin{array}{l}\text { 1. Improved } \\
\text { standard of living } \\
2 . \text { Improved } \\
\text { professionalism } \\
\text { 3. Improved } \\
\text { standard to } \\
\text { international level } \\
\text { 4.better provisions }\end{array}$ & $\begin{array}{l}1 . \\
\text { Recruitment } \\
\text { policy } \\
2 . \text { Require } \\
\text { more training } \\
\text { and } \\
\text { specialization }\end{array}$ & $\begin{array}{l}\text { 1. Difficult to } \\
\text { get the job } \\
\text { 2. Political } \\
\text { influence will } \\
\text { be needed }\end{array}$ \\
\hline 4 & Society & $\begin{array}{l}\text { 1. Economic } \\
\text { development } \\
\text { 2. More revenue } \\
\text { 3. Provision in } \\
\text { international standard } \\
\text { of service } \\
\text { 4. Development of the } \\
\text { community }\end{array}$ & $\begin{array}{l}\text { 1. Increased } \\
\text { employment } \\
\text { opportunities } \\
\text { 2. More tourism } \\
\text { 3. More economic } \\
\text { level of the } \\
\text { community } \\
\text { 4. Increased } \\
\text { globalization }\end{array}$ & $\begin{array}{l}\text { 1. More rules } \\
\text { and regulation } \\
\text { in the airport } \\
\text { 2. More } \\
\text { political } \\
\text { influence. }\end{array}$ & $\begin{array}{l}\text { 1. Change in } \\
\text { the lifestyle of } \\
\text { the people } \\
\text { 2. More traffic }\end{array}$ \\
\hline
\end{tabular}




\section{International Journal of Case Studies in Business, IT, and Education SRINIVAS (IJCSBE), ISSN: 2581-6942, Vol. 4, No. 2, August 2020.

\subsection{ABCD Analysis of PPP Model of MIA from Customers Point of View:}

Table 3 depicts ABCD analysis of MIA from Customers point of view.

Table 3: ABCD analysis from Customers point of view

\begin{tabular}{|c|c|c|c|c|c|}
\hline $\begin{array}{l}\text { S. } \\
\text { No. }\end{array}$ & $\begin{array}{l}\text { Determinant } \\
\text { Issues }\end{array}$ & Advantages & Benefits & Constraints & Disadvantages \\
\hline 1 & $\begin{array}{l}\text { Travelers } \\
\text { Point of } \\
\text { View }\end{array}$ & $\begin{array}{l}\text { 1. Quick service } \\
\text { 2. Quality service } \\
\text { 3. International } \\
\text { standard in the } \\
\text { service } \\
\text { 4. Good Security } \\
\text { System }\end{array}$ & $\begin{array}{l}\text { 1. Increase in } \\
\text { customers } \\
\text { 2. Provision of } \\
\text { quality service } \\
\text { 3. Easily travel to } \\
\text { foreign } \\
\text { countries/ } \\
\text { globalizations } \\
\text { 4. Availability of } \\
\text { quick service }\end{array}$ & $\begin{array}{l}\text { 1. Higher } \\
\text { airfare/ or for } \\
\text { other services } \\
\text { 2. More } \\
\text { passengers }\end{array}$ & $\begin{array}{l}\text { 1. More } \\
\text { passengers, } \\
\text { hence waiting is } \\
\text { increased } \\
\text { 2. Congestion in } \\
\text { Terminal } \\
\text { Building }\end{array}$ \\
\hline 2 & $\begin{array}{l}\text { Airways } \\
\text { point of view }\end{array}$ & $\begin{array}{l}\text { 1. Enhancement of } \\
\text { infrastructure } \\
\text { 2. More } \\
\text { employment } \\
\text { 3. International } \\
\text { standard in airport } \\
\text { 4. More revenue }\end{array}$ & $\begin{array}{l}\text { 1. Better service } \\
\text { to the customer } \\
\text { 2. Better standard } \\
\text { of service } \\
\text { 3. Quick decision } \\
\text { making } \\
\text { 4.Implementation } \\
\text { of their own } \\
\text { policy }\end{array}$ & $\begin{array}{l}\text { 1. More profit } \\
\text { oriented } \\
\text { 2. Work } \\
\text { oriented }\end{array}$ & $\begin{array}{l}\text { 1. Safety } \\
\text { standard may be } \\
\text { comprised due to } \\
\text { profit oriented } \\
\text { 2. More work } \\
\text { pressure for the } \\
\text { employees }\end{array}$ \\
\hline 3 & $\begin{array}{l}\text { Cargo } \\
\text { Business } \\
\text { Point of } \\
\text { View }\end{array}$ & $\begin{array}{l}\text { Increased cargo } \\
\text { business with } \\
\text { higher contact and } \\
\text { quality service }\end{array}$ & More revenue & $\begin{array}{l}\text { More policies } \\
\text { to follow. }\end{array}$ & $\begin{array}{l}\text { Higher cost for } \\
\text { cargo } \\
\text { transportation. }\end{array}$ \\
\hline
\end{tabular}

8.4 Predictive performance of MIA under New Management of Adani Group:

In order to expand the business of MIA by the Management of the Adani Group, it has a strategy of expanding the terminal building so the chaos which the airport is experiencing now with the arrivals and the departures taking place in the same level of the airport will be avoided. It was very difficult during the peak hours, so after the expansion of the terminal building, will cease, as the new arrival area will be constructed in the ground floor level which is equipped with three conveyor belts for both domestic and International arrivals. This will segregate the arrival and departure operations, which will align with the International norm of the airports.

The expansion will also include two more aerobridges which will total to six in future. Due to the increase of facilities like lifts and escalator, there will be quality and quick service to the customers. Other facilities like Tensile fabric canopy with comfortable landscaping and food courts which will attract more customers. With the additional provision of space at the arrival hall, may ease the immigration and customs process, and become passenger-friendly service. There is also an attraction with passenger amenities like fully equipped washrooms, floors, ceilings, to match the International standards. All these promotions will predict the increase in the National and International flyers, thus expanding the business. Based on our observation on figure 2, the Adani group is following right winning strategy to win the offered PPP model of Indian airports in its favour through aggressive bidding strategy. We predict that Adani Group will survive, sustain, compete, unique, and grow\& prosper using optimum strategy which is a mixture of black ocean strategy [60], green ocean strategy [61], red ocean strategy [62], blue ocean strategy [63], and white ocean [64] strategy respectively. 


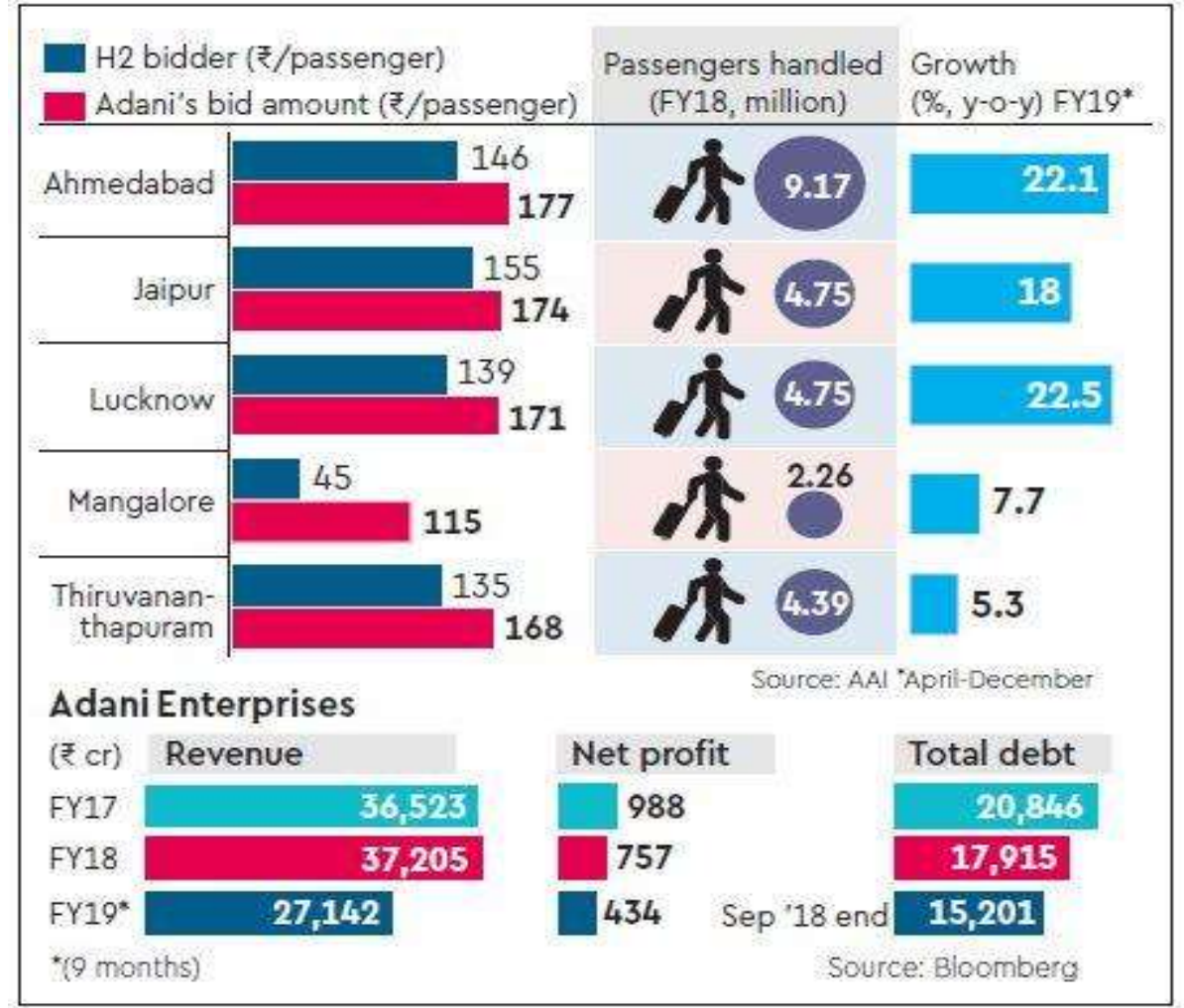

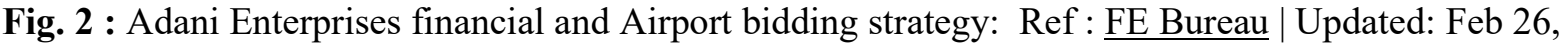
2019.

\section{CONCLUSION :}

Mangalore International airport is now witnessing the development in all areas of trade and industry development and boosting the satisfaction of the participants. After the Adani group of enterprise, took over the airport after the bidding, it assured the airport will be developed to the International standard. The drastic development was seen after implementing the strategies in improving the standard of the airport in terms of infrastructure and service to its customers. The project which is focused by the Adani group is promising for the increase in efficiency in the delivery of the services, expertise in rendering service in par with the International standards and maintaining professionalism. This will enhance the revenue to the AAI which will be the basis for the further investment by the AAI in Tier-II and Tier-III cities and will provide economic development in creating job opportunities to the people in and around the city, and improving the infrastructure.

\section{REFERENCES:}

[1] Aithal, P. S. (2017). Company Analysis - The Beginning Step for Scholarly Research. International Journal of Case Studies in Business, IT and Education (IJCSBE), 1(1), 1-18,

[2] Aithal, P. S, (2017). An Effective Method of Developing Business Case Studies Based on Company analysis. International Journal of Engineering Research and Modern Education (IJERME), 2(1), 16-27.

[3] Aithal, P. S. (2017). Industry Analysis - The First Step in Business Management Scholarly Research. International Journal of Case Studies in Business, IT and Education (IJCSBE), 2(1), 113.

[4] Bergado, Dennes T., et al. (2002). Prefabricated vertical drains (PVDs) in soft Bangkok clay: a case study of the new Bangkok International Airport project. Canadian Geotechnical Journal, 39(2), 304-315.

[5] Jou, R. C., Hensher, D. A., \& Hsu, T. L. (2011). Airport ground access mode choice behaviour after the introduction of a new mode: A case study of Taoyuan International Airport in Taiwan. Transportation Research Part E: Logistics and Transportation Review, 47(3), 371-381. 
[6] Sukumaran, S., \& Sudhakar, K. (2017). Fully solar powered airport: A case study of Cochin International airport. Journal of Air Transport Management, 62, 176-188.

[7] Soliño, A. S., \& Vassallo, J. M. (2009). Using public-private partnerships to expand subways: Madrid-Barajas international airport case study. Journal of Management in Engineering, 25(1), 21 28.

[8] Cirillo, C., \& Xu, R. (2010). Forecasting cyber car use for airport ground access: case study at Baltimore Washington International Airport. Journal of Urban Planning and Development, 136(3), 186-194.

[9] Gilbo, E. (2003, June). Arrival/departure capacity trade off optimization: a case study at the st. louis lambert international airport (stl). In 5th USA/Europe Air Traffic Management R\&D Seminar, 110 .

[10] Sambrani, V. N. (2014). PPP from Asia and African perspective towards infrastructure development: A case study of Greenfield Bangalore International Airport, India. Procedia-Social and Behavioral Sciences, 157(2), 285-295.

[11] Monteiro, A. B. F., \& Hansen, M. (1996). Improvements to airport ground access and behavior of multiple airport system: BART extension to San Francisco International Airport. Transportation Research Record, 1562(1), 38-47.

[12] Hoare, A. G. (1974). International airports as growth poles: A case study of Heathrow Airport. Transactions of the Institute of British Geographers, 75-96.

[13] Lu, C. (2011). The economic benefits and environmental costs of airport operations: Taiwan Taoyuan International Airport. Journal of Air Transport Management, 17(6), 360-363.

[14] Jin-Woo, P., \& Se-Yeon, J. (2011). Transfer passengers' perceptions of airport service quality: a case study of Incheon international airport. International Business Research, 4(3), 75.

[15] Levesque, T. J. (1994). Modelling the effects of airport noise on residential housing markets: a case study of Winnipeg International Airport. Journal of transport economics and policy, 28 (2), 199210.

[16] Correia, A. R., \& Wirasinghe, S. C. (2010). Level of service analysis for airport baggage claim with a case study of the Calgary International Airport. Journal of Advanced Transportation, 44(2), 103112.

[17] Chao, C. C., Lin, H. C., \& Chen, C. Y. (2013). Enhancing airport service quality: A case study of Kaohsiung International Airport. Journal of the Eastern Asia Society for Transportation Studies, 10, 2235-2254.

[18] Chen, H. T., \& Chao, C. C. (2015). Airline choice by passengers from Taiwan and China: A case study of outgoing passengers from Kaohsiung International Airport. Journal of Air Transport Management, 49, 53-63.

[19] George, I. (2013). Modified Importance-Performance Analysis of Airport Facilities-A Case Study of Cochin International Airport Limited. IOSR Journal of Humanities and Social Science, 17(4), 09-15.

[20] Park, J. W., Choi, Y. J., \& Moon, W. C. (2013). Investigating the effects of sales promotions on customer behavioral intentions at duty-free shops: An Incheon International Airport case study. Journal of Airline and Airport Management, 3(1), 18-30.

[21] Yang, J. S., Park, J. W., \& Choi, Y. J. (2015). Passengers Expectations of Airport Service Quality: A Case Study of Jeju International Airport. International Journal of Business and Social Research, 5(7), 30-37.

[22] Akar, G. (2013). Ground access to airports, case study: Port Columbus International Airport. Journal of Air Transport Management, 30, 25-31. 
[23] Wu, C., Han, J., \& Hayashi, Y. (2011). Airport attractiveness analysis through a gravity model: A case study of Chubu International Airport in Japan. In Proceedings of the Eastern Asia Society for Transportation Studies Vol. 8, 419-419.

[24] Pels, E., Nijkamp, P., \& Rietveld, P. (2003). Access to and competition between airports: a case study for the San Francisco Bay area. Transportation Research Part A: Policy and Practice, 37(1), 71-83.

[25] Yoon, S. W., \& Jeong, S. J. (2015). An alternative methodology for planning baggage carousel capacity expansion: A case study of Incheon International Airport. Journal of Air Transport Management, 42, 63-74.

[26] Eshtaiwi, M., Badi, I., Abdulshahed, A., \& Erkan, T. E. (2018). Determination of key performance indicators for measuring airport success: A case study in Libya. Journal of Air Transport Management, 68, 28-34.

[27] Shahin, A., Janatyan, N., \& Nasirzaheh, N. (2012). Service quality robust design-with a case study in airport services. International Journal of Productivity and Quality Management, 9(3), 404-421.

[28] Davison, L., Ryley, T., \& Snelgrove, M. (2010). Regional airports in a competitive market: A case study of Cardiff International Airport. Journal of Airport Management, 4(2), 178-194.

[29] Lu, H. A., \& Mao, Y. R. (2015). Evaluation of airport conditions to attract foreign low-cost carriers: A case study of Taiwan. Journal of Air Transport Management, 42, 297-305.

[30] Goh, J. C. L., Zuo, M., \& Pan, S. L. (2010). Transforming Organizational Capabilities into Agile IT Adoption: A Case Study of Beijing International Airport. In ICIS, 69.

[31] Kurniawan, R., Sebhatu, S. P., \& Davoudi, S. (2017, January). Passengers' Perspective Toward Airport Service Quality (ASQ) (Case Study at Soekarno-Hatta International Airport). In Journal of the Civil Engineering Forum, 3(1), 21-32.

[32] Yao, S. M., Chen, C. H., Wang, S. G., CUI, X., \& CHEN, Z. G. (2006). International airport location and planning: a case study of New White Clouds Airport in Guangzhou. Human Geography, 21(1), 56-59.

[33] Rajan, T. A., Sharad, S., \& Sinha, S. (2009). PPP in Greenfield airport development: a case study of Cochin international airport limited. Policy, Management and Finance of Public-Private Partnerships, 97-122.

[34] Tsai, W. H., Hsu, W., \& Chou, W. C. (2011). A gap analysis model for improving airport service quality. Total Quality Management \& Business Excellence, 22(10), 1025-1040.

[35] Adisasmita, S. A. (2012). Passenger Perception on Airport Terminal Facilities Performance (Case Study: Soekarno-Hatta International Airport, Indonesia). International Journal of Engineering \& Technology IJET-IJENS, 12(2),1-9.

[36] Lieshout, R., \& Matsumoto, H. (2012). New international services and the competitiveness of Tokyo International Airport. Journal of Transport Geography, 22, 53-64.

[37] Walala, M., \& Mutinda, E. M. (2013). Evaluation of sustainable development in aviation industry: A case study of Kenya Airways (KQ) and Eldoret international airport. Journal of Economics and Sustainable Development, 4(9), 61- 74.

[38] Müller, C., \& Gosling, G. D. (1991). A framework for evaluating level of service for airport terminals. Transportation Planning and Technology, 16(1), 45-61.

[39] Baxter, G., Srisaeng, P., \& Wild, G. (2018). Sustainable airport energy management: The case of Kansai International Airport. International Journal for Traffic \& Transport Engineering, 8(3), 334358. 
[40] Falvo, M. C., Santi, F., Acri, R., \& Manzan, E. (2015, June). Sustainable airports and NZEB: The real case of Rome International Airport. In 2015 IEEE 15th International Conference on Environment and Electrical Engineering (EEEIC), 1492-1497.

[41] Gupta, A. (2013). Greenfield Airport Development in India: A Case Study of Bangalore International Airport. Available at SSRN, https://ssrn.com/abstract=2311993.

[42] Lynes, J. K., \& Dredge, D. (2006). Going green: Motivations for environmental commitment in the airline industry. A case study of Scandinavian Airlines. Journal of sustainable tourism, 14(2), 116138.

[43] Parameshwar, H. K. (2011, December). Solid waste management in airports: A case study of Bangalore International Airport. In International Conference on Green technology and environmental Conservation, 152-158.

[44] Kim, M. H., Park, J. W., \& Choi, Y. J. (2016). A study on the effect of airport choice attributes on airport users' satisfaction and behavioural intentions: The case of Gimpo International Airport. Journal of Airport Management, 10(2), 145-157.

[45] Li, L., \& Loo, B. P. (2016). Impact analysis of airport infrastructure within a sustainability framework: Case studies on Hong Kong International Airport. International Journal of Sustainable Transportation, 10(9), 781-793.

[46] Ryu, Y. K., \& Park, J. W. (2019). Investigating the Effect of Experience in an Airport on Pleasure, Satisfaction, and Airport Image: A Case Study on Incheon International Airport. Sustainability, 11(17), 4616, 1-11.

[47] Bhadra, D. (2008). The opportunities and challenges of civil aviation in India, Part 1: Airport sector liberalisation. Journal of Airport Management, 3(1), 13-36.

[48] Raghunath, S. (2010). Airport privatisation in India: Investment opportunities in the next phase of development. Journal of Airport Management, 4(3), 235-251.

[49] Bhadra, D. (2009). The opportunities and challenges of civil aviation in India, Part 2: Communications, navigation, and surveillance in air traffic management. Journal of Airport Management, 3(3), 246-262.

[50] Kashiramka, S., Banerjee, R., Kumar, A., \& Jain, P. K. (2016). Efficiency Analysis of Airports in India in a Changing Environment: A Data Envelopment Analysis Approach. Journal of Transport Economics and Policy (JTEP), 50(4), 384-403.

[51] Manzoor, K. P. (2010). Airport Privatization in India: Importance and Challenges. IUP Journal of Infrastructure, 8(4), 58-69.

[52] Vinayak, A. J. (2012). Global passengers key to traffic growth at Mangalore airport. https://www.thehindubusinessline.com/economy/logistics/global-passengers-key-to-trafficgrowth-at-mangalore-airport/article20395223.ecel Retrieved on 05/07/2020.

[53] Direct flights from Mangalore (IXE) - Flight Connections [Internet]. Flightconnections.com. 2020 [referred on2 July 2020]. Available from: https://www.flightconnections.com/flights-frommangalore-ixe) there are 6 domestic flights from Mangalore.

[54] Airport to be expanded. [Internet]. News on Projects. 2020 [Referred on July 2020]. Available from: https://www.newsonprojects.com/news/mangalore-airport-to-be-expanded.

[55] Satchelone.com. 2020 [referred on 2 July 2020]. Available from: https://www.satchelone.com/login

[56] National, Science, Sports, World, Variety, Education et al. Time to put Mangalore airport on the radar screen [Internet]. @businessline. 2020 [referred on 3 July 2020]. Available from: https://www.thehindubusinessline.com/economy/logistics/Time-to-put-Mangalore-airport-on-theradar-screen/article20245777.ece 
[57] http://Report on Accident to Air India Express Boeing 737-800 aircraft VT-AXV on $22^{\text {nd }}$ May 2010 at Mangalore.

[58] Aithal, P. S., Shailashree, V.T. \& Suresh Kumar, P. M. (2015). A New ABCD Technique to Analyze Business Models \& Concepts. International Journal of Management, IT and Engineering (IJMIE), 5(4), 409 - 423.

[59] Aithal, P. S., (2016). Study on ABCD Analysis Technique for Business Models, business strategies, Operating Concepts \& Business Systems. International Journal in Management and Social Science, 4(1), 98-115.

[60] Aithal, P. S., \& Kumar, P. M. (2015). Black Ocean Strategy-A Probe into a new type of Strategy used for Organizational Success. GE-International Journal of Management Research (GEIJMR), 3(8), 45-65.

[61] Hou Shengtian (2007). Green ocean strategy: Obtaining sustainable competitive advantage, Beijing: Tsinghua University Press, 183-197.

[62] Porter M. E. (1997). Competitive strategy. Measuring Business Excellence, 1(2), 12-17.

[63] Kim W. C., \& Mauborgne, R. (2005). Blue ocean strategy. California Management Review, 47(3), 105-121.

[64] Aithal P. S. (2016). The concept of Ideal Strategy \& its realization using White Ocean Mixed Strategy. International Journal of Management Sciences and Business Research (IJMSBR), 5(4), 171-179. 